\title{
Devonian siliciclastic rocks of the Babí lom locality (southern Moravia, Czech Republic): sedimentary environment reconstruction and provenance study
}

\author{
Jurand WOJEWODA ${ }^{1, *}$, Slavomír NEHYBA ${ }^{2}$, Helena GILÍKOVÁ ${ }^{3}$ and David BURIÁNEK ${ }^{3}$ \\ 1 Wrocław University, Institute of Geological Sciences, Department of Structural Geology and Geological Mapping, \\ PI. Maksa Borna 9, 50-204 Wrocław, Poland \\ 2 Masaryk University, Faculty of Science, Department of Geological Sciences, Kotlářská 267/2, 611-37 Brno, Czech Republic \\ 3 Czech Geological Survey, Branch Brno, Leitnerova 22, 658-69 Brno, Czech Republic
}

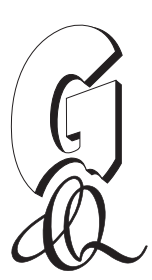

\begin{abstract}
Wojewoda, J., Nehyba, S., Gilíková, H., Buriánek, D., 2015. Devonian siliciclastic rocks of the Babí lom locality (southern Moravia, Czech Republic): sedimentary environment reconstruction and provenance study. Geological Quarterly, 59 (1): 229-238, doi: 10.7306/gq.1205

Anchimetamorphosed sandstones and conglomerates of the so-called "Basal Devonian Clastics", that build a hill (ridge) named Babí lom, are considered to be of Lower to Middle Devonian age. Although they are strongly tectonically affected, many sedimentary features are well-preserved and distinct. Both the facies and structures typical of alluvial fans and rivers were recognized in the sedimentary association at Babí lom. Among others, there are channel lags with imbricated grains, cross-bedding, and debrites. The way-up direction is clearly seen via repetitive coarsening-upwards sequences. Assuming a lack of rotation of the succession in the $X-Y$ plane, the main palaeodrainage was towards the north and the major supply of material was from the east. The high maturity of the rocks suggests derivation from older deposits and/or highly weathered source rocks. The magmatic rocks of the Brunovistulicum are possibly the primary source of the sediments.
\end{abstract}

Key words: southern Moravia, Brno Massif, Devonian siliciclastics, facies analysis, heavy minerals, alluvial fan.

\section{INTRODUCTION}

In Czech geological literature, the term "Basal Devonian Clastics" is used for the red monomictic quartz-pebble conglomerates, quartz arenites, subarkoses, and arkoses with interbeds of laminated siltstone, as well as for polymict conglomerates which are exposed in several areas of southern Moravia (e.g., Dvořák, 1978, 1998; Gilíková, 2007). These deposits have also been named the Old Red Sediments (Skoček, 1980; Zukalová and Chlupáč, 1982). The best known occurrences of these clastics are in the Moravian Karst area, between Bílovice nad Svitavou and Ochoz u Brna (Gilíková et al., 2010), in the Babí lom - Červený kopec Zone between Svinošice and Lelekovice, and in the Čebínka Zone near the town of Tišnov (Hanžl et al., 2007). These rocks are also known from numerous deep boreholes along the southeastern margin of the Bohemian Massif (Vavrdová et al., 2003; Mikuláš et al., 2008).

Spectacular outcrops of Devonian clastic rocks in the Babí lom destination (Fig. 1) have attracted the interest of a number

\footnotetext{
* Corresponding author, e-mail: jurand.wojewoda@ing.uni.wroc.pl Received: January 6, 2014; accepted: October 14, 2014; first published online: December 11, 2014
}

of investigators (Dvořák, 1960; Melichar et al., 1999; Nehyba et al., 2001; Gilíková, 2007; Buriánek et al., 2008). The aim of this paper is to present results of sedimentological and petrographical studies carried out in several isolated exposures in this zone, that address the questions of:

- depositional processes and settings,

- evolution of the depositional environment,

- source areas,

- and demonstrate applicability of sedimentological techniques in tectonically deformed coarse clastic.

\section{GEOLOGICAL SETTING}

The siliciclastic sedimentary rocks of the Babí lom Červený kopec Zone crop out over the $\mathrm{N}-\mathrm{S}$ elongated area bordered by the metabasites of the so-called Central Basic Belt to the west and the granodiorites of the Brno Batholith to the east (see Fig. 1). The zone mainly consists of quartz-pebble conglomerates, typically thickly-bedded. According to geophysical data, the depth-range of these presumably terrestrial sedimentary rocks is about $600 \mathrm{~m}$, and is limited by a tectonic boundary (fault?) (Melichar et al., 1999; Hanžl et al., 2007). Their exact stratigraphic position is not known because of the absence of any palaeontological data. Nevertheless, the Early to Middle Devonian age is estimated, based on comparison to the Middle 


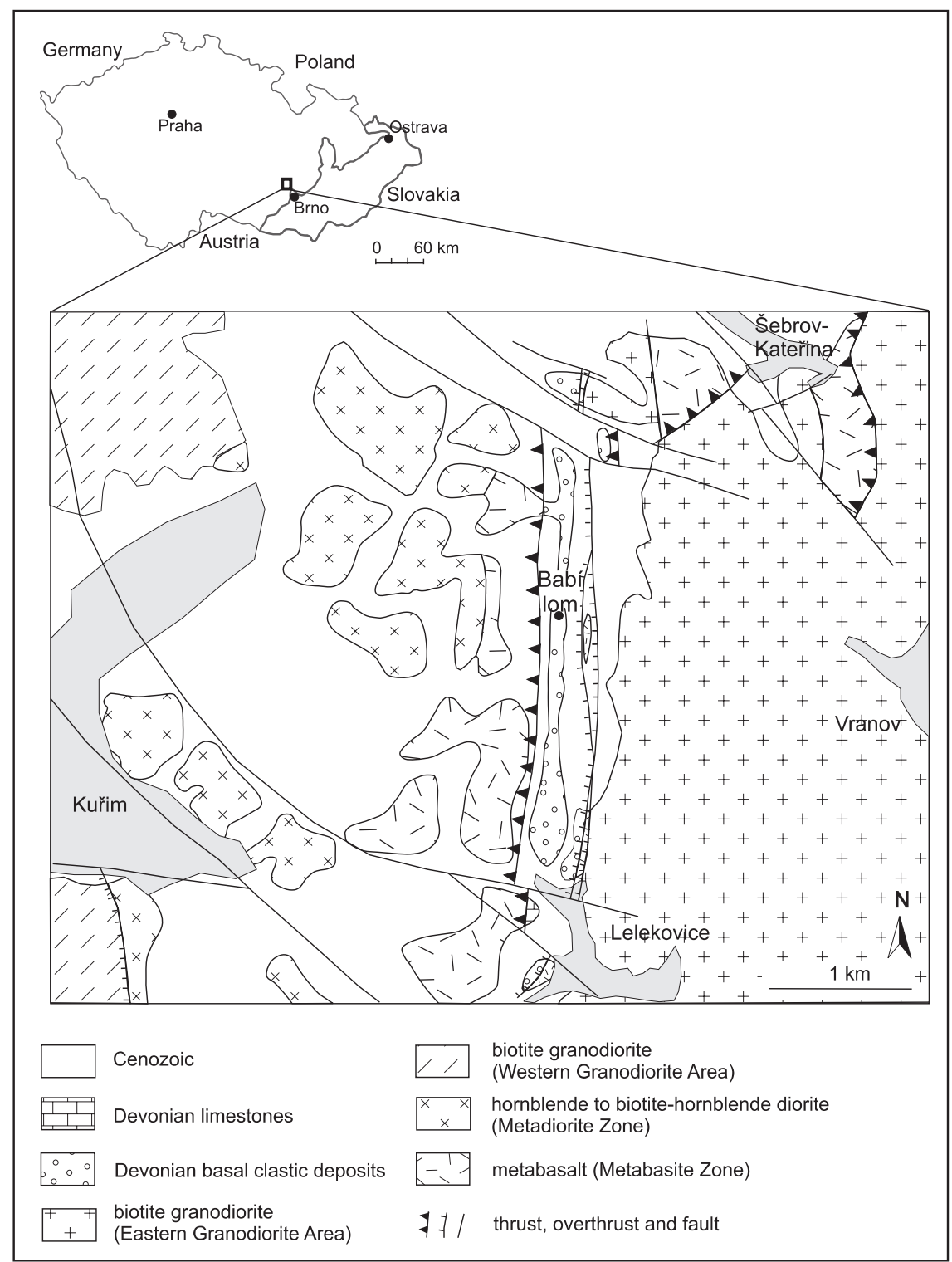

Fig. 1. Geological map of the locality studied

Modified map according Hanžl et al. (2007)

and Upper Givetian limestone located a few hundred metres to the south from the Babí lom locality (Fig. 1; Hladil, 1992; Hanžl et al., 2007).

The sandstone and conglomerate beds dip steeply $\left(60-85^{\circ}\right)$ to the west $\left(260-300^{\circ}\right)$ and form a striking rocky ridge morphology at present. The rocks have been deformed under brittle and brittle-ductile regimes, as indicated by sets of stylolites, veins, and shear zones (Roupec, 1994).

There also occur isolated blocks of siliciclastic rocks, supposedly resulting from frost weathering during the Pleistocene, which were transported over a distance greater than $1 \mathrm{~km}$ from the source rock at the Babí lom locality.

\section{METHODS OF STUDY}

The Babí lom morphological ridge consists of a suite of isolated rock nests which have limited vertical and lateral extent. This makes the construction of a continuous sedimentary log profile extremely difficult. The lithofacial subdivision and palaeocurrent estimations were based on textural and structural features, following Walker and James (1992) and Graham (2004). Seven major lithofacies were recognized. Their interpretation and distribution provided the basis to build a schematic section of the succession, as well as to estimate the sedimentary and environmental settings and their evolution in time (Fig. 2). Facies codes are used according to Miall (1996). The 

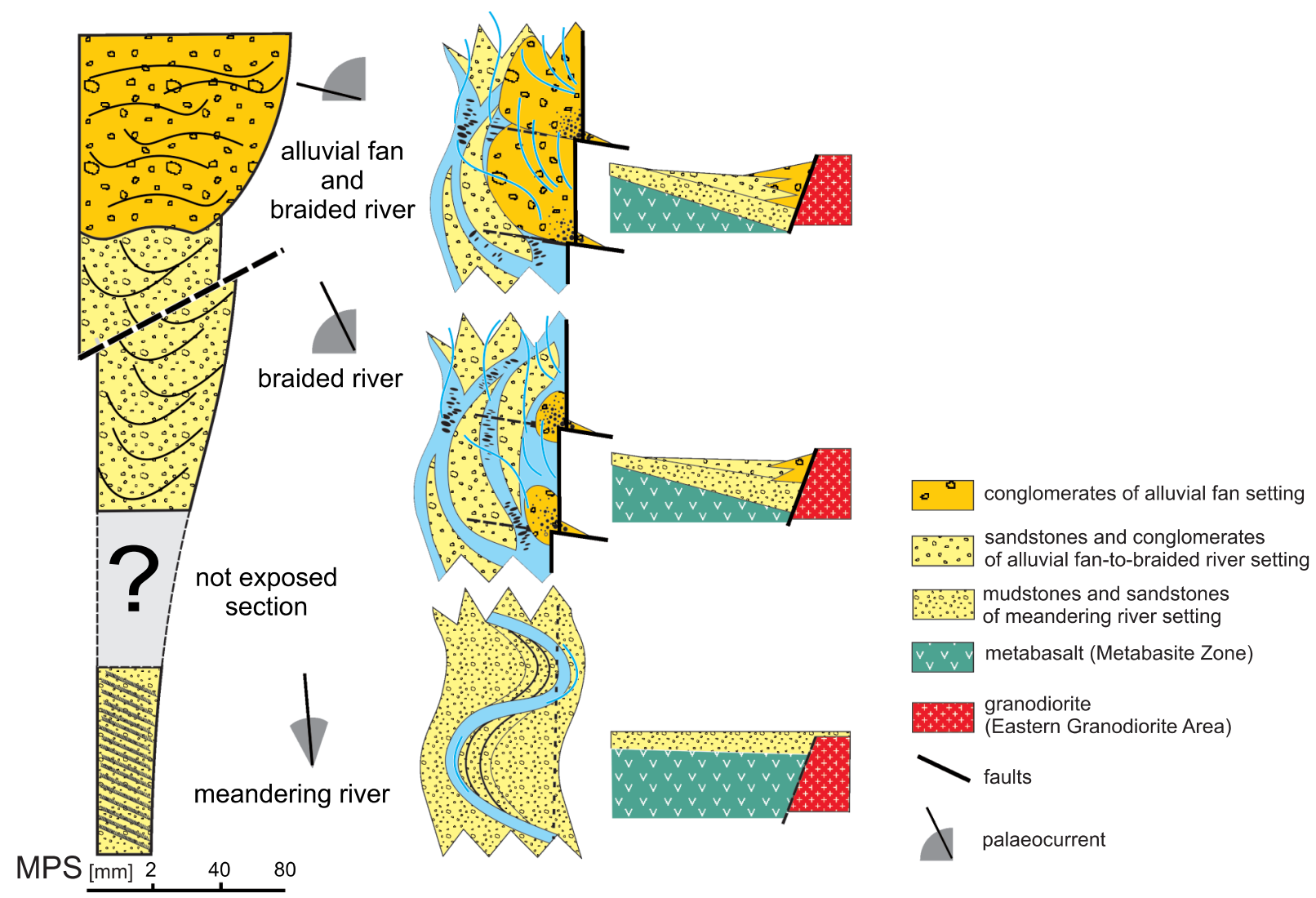

Fig. 2. Schematic sedimentary log of Babí lom locality Devonian basal clastics with elementary sketch of depositional environment

MPS - maximum pebble size

maximum pebble size (MPS) was obtained from the measurement of the longest axis (A-axis) of the 10 largest found clasts.

Thin-sections of the sandstones from the lower part of the section were observed under a polarizing microscope and a CL-microscope with a "hot cathode" (CL-microscope SimonNeuser HC2-LM, Faculty of Science, Masaryk University, Brno, Czech Republic). Translucent heavy mineral assemblages (grain size $0.06-0.25 \mathrm{~mm}$ ) were studied in only one sample. The chemical compositions of the selected heavy minerals ( 8 garnet grains and 5 tourmaline grains) were studied in further detail using the Cameca SX-100 electron microprobe at the Department of Geological Sciences, Faculty of Science, Masaryk University in Brno. The chemical compositions of individual grains were investigated in a wave dispersion mode under the following conditions: $15 \mathrm{kV}$ acceleration voltage, $5 \mu \mathrm{m}$ of the electron beam diameter, $30 \mathrm{nA}$ current, integration time $20 \mathrm{~s}$. Solely $\mathrm{K} \alpha \mathrm{X}$-ray lines were used as standards: augite $(\mathrm{Si}, \mathrm{Mg})$, orthoclase $(\mathrm{K})$, jadeite $(\mathrm{Na})$, chromite $(\mathrm{Cr})$, almandine $(\mathrm{Al})$, andradite $(\mathrm{Fe}, \mathrm{Ca})$, rhodonite $(\mathrm{Mn}), \mathrm{TiO}_{2}(\mathrm{Ti})$. The formulae of garnets were recalculated assuming 12 oxygen atoms per formula unit (apfu). Formulae of tourmalines were obtained on the basis of $31(\mathrm{O}, \mathrm{OH}, \mathrm{F})$, assuming $\mathrm{OH}+\mathrm{F}=4$ apfu and $\mathrm{B}=3$ apfu. The abbreviations of mineral names correspond to Kretz (1983).

\section{LITHOFACIES DESCRIPTION}

Facies $\mathrm{Sr}$ (Fig. $3 \mathrm{~A})$ is represented by reddish-brown ripple cross-stratified non-uniformly grained sandstone. It was recog- nized in the lowermost section of the sedimentary section. Two subfacies of $\mathrm{Sr}$ can be identified: fine-grained, well-sorted sandstone, and medium- to coarse-grained, poorly-sorted sandstone, locally with siltstone flasers. Although both subfacies alternate irregularly, the coarser-grained one seems to be more common up-profile. The Sr facies cosets are at least $3 \mathrm{~m}$ thick, however, the bed shapes could not be specified due to the quality and size of the exposure.

Reddish-brown, very fine planar-laminated sandstone to siltstone represents the facies Ml. Usually it forms ca. $30 \mathrm{~cm}$ thick intralayers within the upper part of the Sr facies coset. Siltstone flasers recognised within the coarse-grained Sr subfacies are macroscopically similar to facies Ml.

Facies Sp (Fig. 3C) consists of poorly sorted coarsegrained, low angle planar cross-stratified sandstone with scattered quartz pebbles (MPS is $1.5 \mathrm{~cm}$ ), whereas facies St (Fig. $3 B, D)$ differs from the upper one only by the presence of trough cross-stratification. The set tops of St facies are usually erosional (concave), whereas their bases are sharp and uneven. The thickness of individual sets of facies St and Sp does not exceed $30 \mathrm{~cm}$. Facies Sp and St were both recognized in several small exposures in the middle part of the section.

Facies Gt (Figs. 3D and 4C) is a clast to matrix-supported, trough cross-stratified conglomerate. Pebble shapes are very varied. The preferred orientation of the longest axes of the elongated and bladed pebbles is parallel to the axis of the bedding troughs. The pebbles are sub-angular to sub-rounded. Enrichment of the pebbles (MPS of quartz is $5 \mathrm{~cm}$ ) along the channel bottoms, forming "pebble clusters" (Fig. 4B; Teisseyre, 1977; 

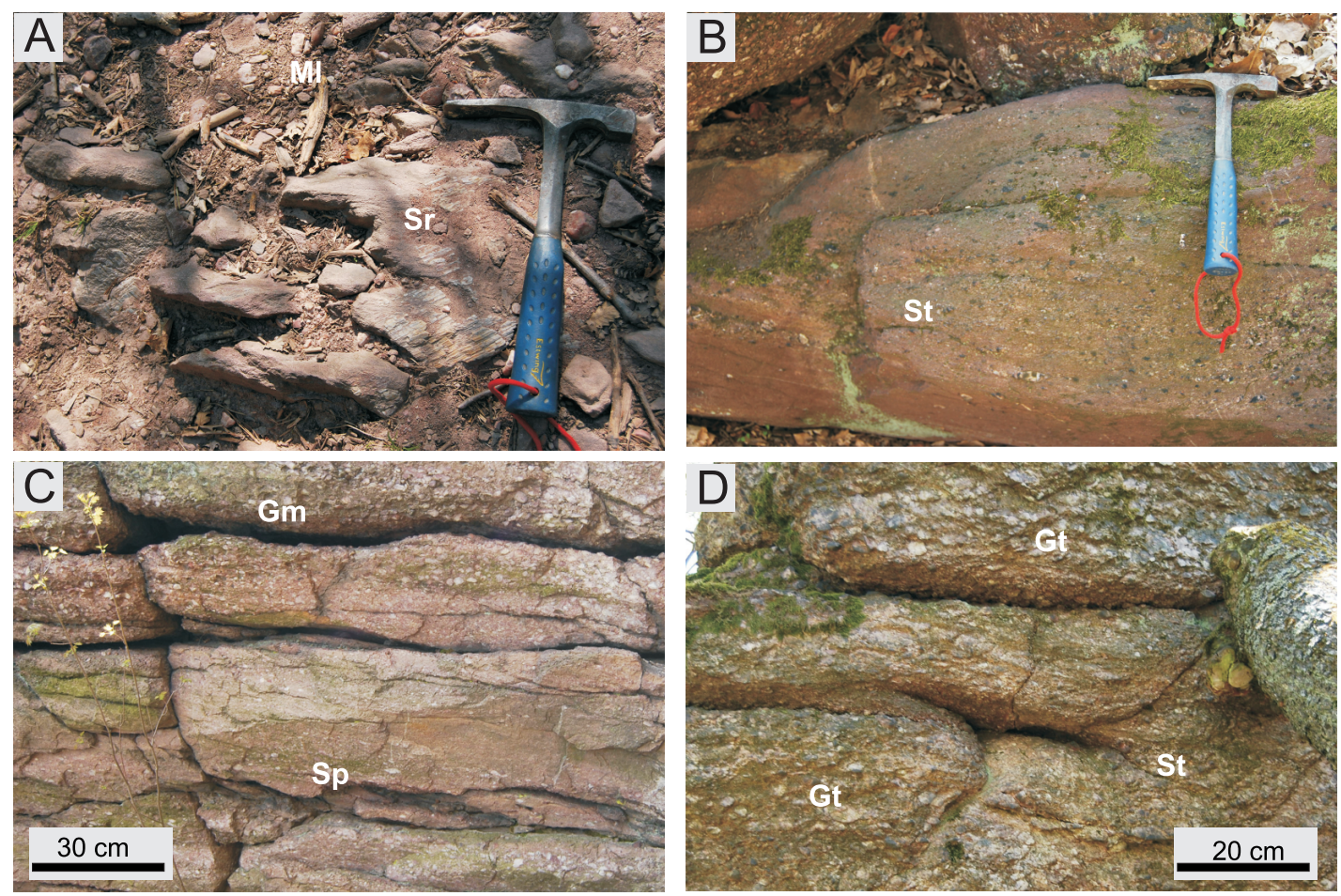

Fig. 3. Devonian basal clastic sediments (sandstones and conglomerates)

A - ripple cross-laminated sandstone (facies $\mathrm{Sr}$ ) and laminated muds (facies $\mathrm{MI}$ ), B - trough-cross bedded sandstone (facies St), $\mathbf{C}$ - planar cross-bedded sandstone (facies Sp) and massive conglomerates (facies Gm), D trough-cross bedded sandy conglomerates (facies St) and clast to matrix-supported, trough cross-stratified conglomerate (facies Gt)

Hein, 1984; Wittenberg and Newson, 2005), was locally documented. The beds usually have erosional and convex bases, however, individual beds reveal a shape of broad channels with compound infill and numerous reactivation surfaces. The thickness of the individual channels reaches up to several metres.

Facies Gm (Figs. 3C and 4D) consists of crude planar-stratified to structureless conglomerate. The conglomerate is clast to matrix (sandy) supported. The MPS of quartz pebbles is 4 $\mathrm{cm}$, however, the majority of grains do not exceed $2 \mathrm{~cm}$. Bedding-parallel preferred orientation of the longest axes of the elongated and bladed pebbles was rarely recognized. The beds of $\mathrm{Gm}$ facies have irregular and erosive bases and wedge- or tabular-shapes.

Reddish-brown coarse- to very coarse-grained planarstratified sandstone, poorly sorted with an admixture of quartz pebbles (MPS up to $1.5 \mathrm{~cm}$ ), was assigned as facies SI. Intrabeds of facies SI were recognized within the main beds of facies $\mathrm{Gm}$. Sandstone beds of facies SI typically have lenticular shapes and are about $20 \mathrm{~cm}$ thick. The bases are sharp, uneven, and irregular while the tops are erosional. Facies $\mathrm{Gm}$ with intrabeds of facies SI was recognized in the upper part of the section studied in several small exposures. Conglomerates of facies $\mathrm{Gm}$ dominate in the uppermost part of the section, where they locally alternate with facies Gt. Convex-down bases of the beds and erosive tops are typical. Individual beds have tabular- to broadly-convex shapes and can be traced over a distance of several metres (mostly over the lateral extent of the exposures).

\section{DEPOSITIONAL ENVIRONMENT}

Facies $\mathrm{Sr}$ and $\mathrm{Ml}$ were recognized in the lower part of the section. They are related to traction currents and shallow water conditions. Facies $\mathrm{Sr}$ is interpreted as a product of deposition from waning currents under the lower flow regime. It can be connected with the topmost parts of the dunes or the bar flanks. Facies Ml was deposited mainly from suspension settling, with very limited bedload transport (weak currents). Such deposition over the upper parts of sandy beds probably reflects the conditions in low-relief flood plains (cf. Allen, 1964; Jackson, 1978, 1981; Miall, 1985), or so-called "overbank fines" (cf. Miall, 1996). The overbank deposits are usually interpreted as evidence of a fluvial setting, especially of high sinuosity to meandering style. Significant volumes of fine-grained floodplain material are not incorporated within braided stream facies models due to the significant role of lateral reworking (Miall, 1996). However, a number of ancient braided systems contain significant amounts of preserved floodplain material, complementing the coarse-grained channel fill (e.g., Desloges and Church, 1987; Mack and Seager, 1990; Bentham et al., 1993). Enhanced floodplain preservation (deposits in association with coarse-grained braided fluvial deposits or fluvial fan) could be connected with the rapid formation of the depositional space volume, e.g. in response to rapid tectonic subsidence and/or scarp formation. Here, we interpret the lower part of the section (see Fig. 4) as having originated due to deposition in a marginal/lateral part of a fluvial (meandering?) system, the forma- 

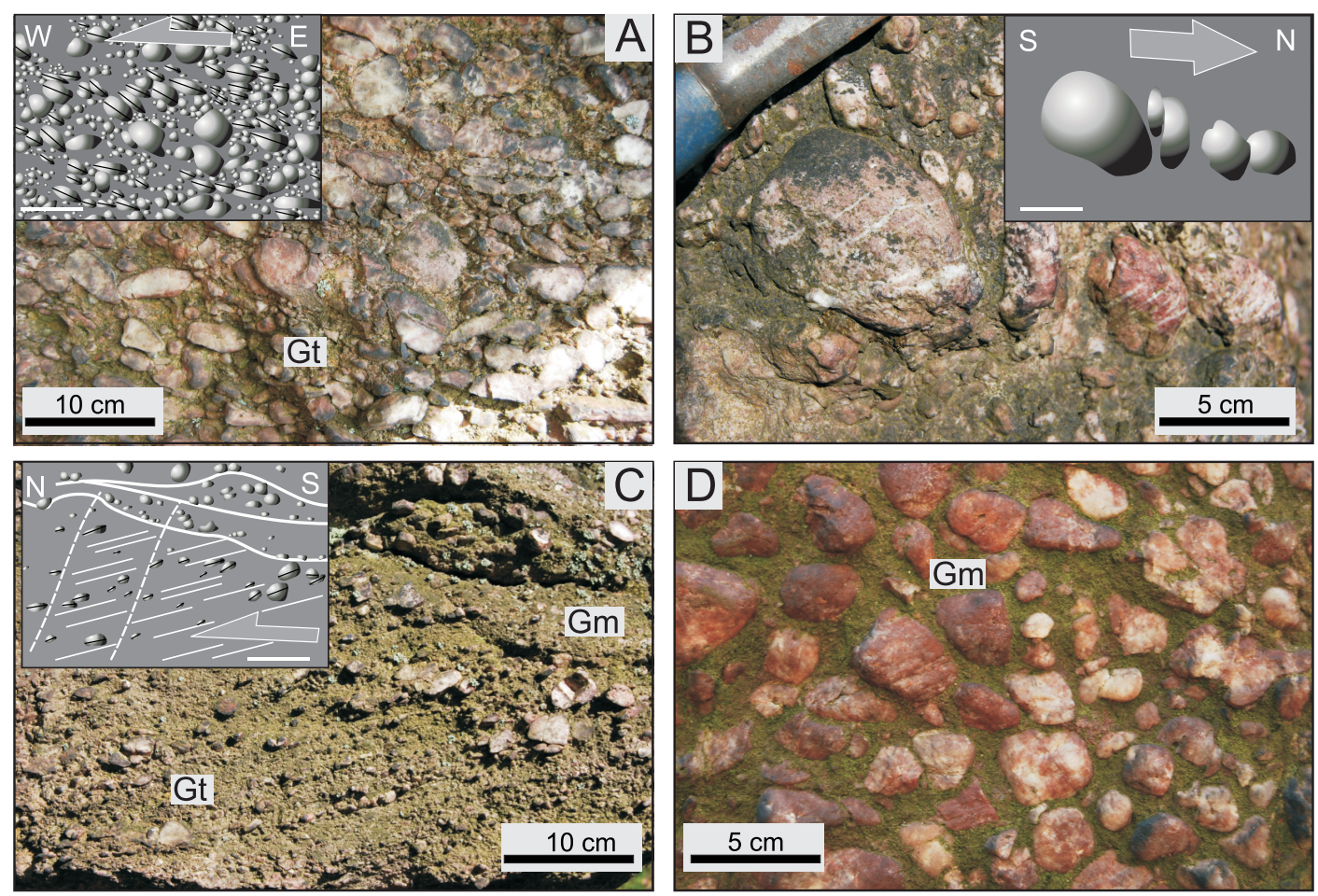

Fig. 4. Devonian basal clastic sediments (conglomerates)

A - massive conglomerate showing up-current clast imbrication; $\mathbf{B}$ - pebble cluster ripple; C - trough cross-bedded conglomerate (facies $\mathrm{Gt}$ ) and massive conglomerate (facies $\mathrm{Gm}$ ), D - matrix-supported grains (facies $\mathrm{Gm}$ )

tion of attached bars (point bars?), and deposition in an adjacent overbank/floodplain area.

The middle part of the section consists of facies Sp and St. Facies Sp represents foresets formed on the lee-sides of migrating sand dunes under the lower flow regime. A higher content of pebbles and granules along the channel bases can be explained by "gravel overpassing", which is connected with bedform migration (cf. Miall, 1996). Facies St is interpreted as being deposited in traction stream-flows under the lower flow regime. It can be related to the migration of $3 D$ dunes, which filled minor channels or depressions, e.g. cut and fill structures. This part of the succession is interpreted as a sediment assemblage of dominantly mid-channel bars and dunes (Bridge, 1993; Miall, 1996).

The upper part of the succession, primarily consisting of conglomerates of facies $\mathrm{Gt}$, is interpreted as a product of deposition from steady traction flows and the formation of gravel channel bars and dunes, or the infill of minor channels. Facies $\mathrm{Gt}$ is connected with two partial depositional environments. Alternation of facies Gt with facies St and Sp is interpreted as the sediment of a braided river, with the dominant role of migrating in-channel bedforms (see Fig. 4). Other depositional environments connected with facies $\mathrm{Gt}$ are the distal or medial parts of an alluvial fan, where facies $\mathrm{Gt}$ alternates with facies $\mathrm{Gm}$ - such a situation was recognized in the uppermost part of the profile. Poorly developed horizontal stratification and very rare grain imbrication within facies $\mathrm{Gm}$ suggests rapid deposition from traction flows as low-relief overgrowing gravel carpets. This facies represents the coarsest and least mobile bed-load material, deposited in the axial parts of channels immediately after the erosional stage as a response to the diminishing of the peak flood. The uppermost part of the section is interpreted as a sedi- ment assemblage typical of alluvial fan settings. We can only speculate about the "wet" type of the fan, with episodic sheet flood deposition and significant variations in discharge. Sheet flood-dominated systems are often connected with an arid to semi-arid climate, with a possibly seasonal and strongly fluctuating water discharge (cf. Blair and McPherson, 1994; Hampton and Horton, 2007).

The unsteady flow condition and rapid changes in the flow dynamics are also supported by the common occurrence of facies SI within the conglomerates of facies $\mathrm{Gm}$. Facies SI reflects deposition from traction flows near a transition phase between the lower and upper flow regimes (both upper and lower flow regime plane beds). SI facies can be related to the final stages of the channel filling, washed out phases over the top of the dune/sheet, or aggradation on a plane or low-angle bed in peripheral fan sections. Alternation of facies SI and massive conglomerate $\mathrm{Gm}$ is, according to Todd (1989) and Blair (1999), typical of deposition in alluvial fans, dominated by a surficial stream tributary system.

\section{PETROGRAPHY AND HEAVY MINERAL COMPOSITION}

Quartz to arkosic sandstone, reflecting relatively good mechanical reworking, constitutes the matrix in the conglomeratic facies and also in facies Sr. Sub-rounded monocrystalline quartz grains dominate in sandstone facies (Fig. 5). Partly sericitized feldspars occur in variable amounts (up to $10 \mathrm{wt} . \%$ ). The perthites were observed in K-feldspar only occasionally. Micas constitute up to $2 \mathrm{wt}$. \% of the mineral components. Muscovite predomi- 
nates in arkosic sandstone, but baueritized biotite is also present. Granitoids, volcanites, gneisses, quartzites, and siltstones were observed as rock fragments. The cement has a coat-pore character and is composed of sericite, small grains of quartz, and Fe oxides and hydroxides, which usually also form grain coat-

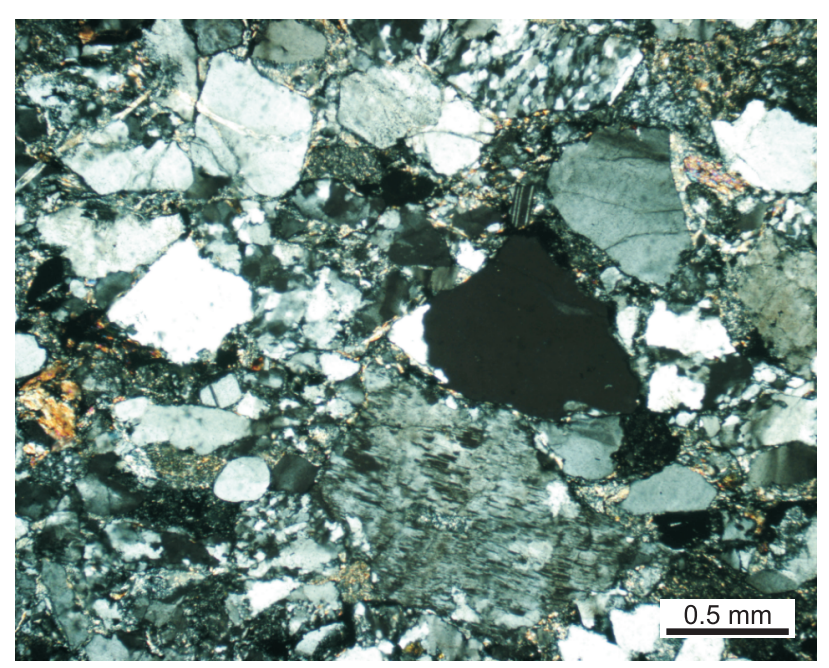

Fig. 5. Microphotograph of arkosic sandstone ings. Silicification within/of the quartz grains is common. Several types of quartz grains (without luminescence, light blue, blue and red) were observed under a CL microscope (Fig. 6). The twinning and carbonization of some grains were determined in feldspars using CL microscopy (Gilíková, 2007).

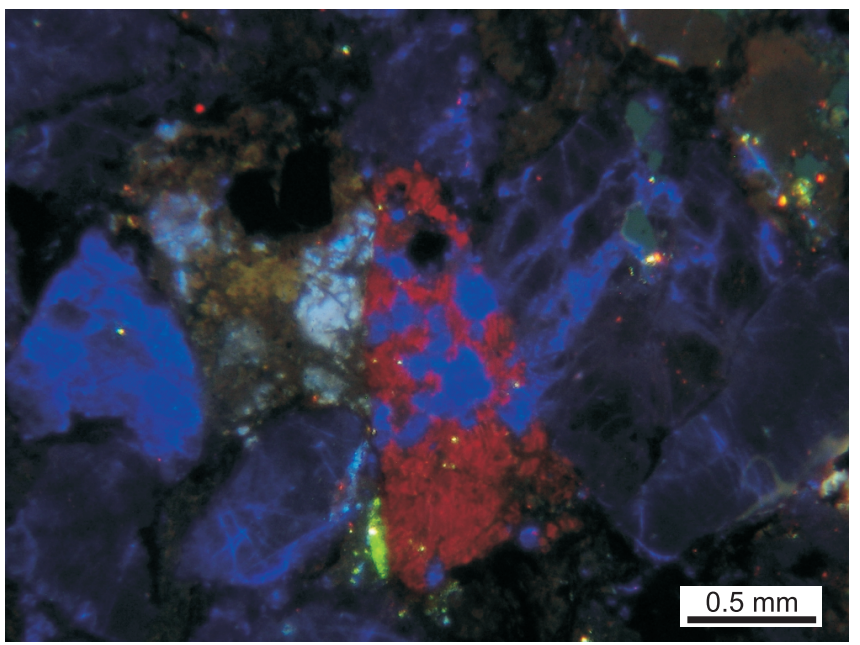

Fig. 6. The several types of quartz in CL-microscope

Representative chemical composition of garnet

\begin{tabular}{|l|c|c|c|c|c|c|c|c|}
\hline \multicolumn{1}{|c|}{ Grain } & $\mathrm{HG} 16 / 198$ & $\mathrm{HG} 16 / 200$ & $\mathrm{HG} 16 / 201$ & $\mathrm{HG} 16 / 203$ & $\mathrm{HG} 16 / 204$ & $\mathrm{HG} 16 / 205$ & $\mathrm{HG} 16 / 206$ & $\mathrm{HG} 16 / 207$ \\
\hline $\mathrm{SiO}_{2}$ & 36.56 & 36.22 & 37.53 & 38.27 & 37.54 & 37.88 & 37.16 & 37.80 \\
\hline $\mathrm{TiO}_{2}$ & 0.30 & 0.09 & 0.00 & 0.00 & 0.07 & 0.06 & 0.14 & 0.00 \\
\hline $\mathrm{Al}_{2} \mathrm{O}_{3}$ & 20.21 & 19.85 & 20.80 & 22.25 & 20.58 & 20.89 & 20.68 & 20.86 \\
\hline $\mathrm{Fe}_{2} \mathrm{O}_{3}{ }^{\text {calc }}$ & 0.69 & 1.64 & 0.41 & 1.12 & 0.76 & 0.34 & 0.46 & 0.17 \\
\hline $\mathrm{FeO}^{\text {calc }}$ & 3.65 & 18.34 & 21.70 & 13.23 & 17.58 & 21.57 & 12.73 & 27.87 \\
\hline $\mathrm{MnO}$ & 35.59 & 21.83 & 14.68 & 22.62 & 14.07 & 9.44 & 17.81 & 6.53 \\
\hline $\mathrm{MgO}$ & 0.40 & 1.37 & 2.32 & 4.25 & 1.80 & 2.91 & 0.00 & 3.16 \\
\hline $\mathrm{CaO}$ & 2.79 & 0.39 & 3.25 & 1.59 & 7.74 & 7.04 & 10.77 & 3.96 \\
\hline $\mathrm{Y} \mathrm{O}_{5}$ & 0.00 & 0.24 & 0.06 & 0.00 & 0.00 & 0.00 & 0.00 & 0.07 \\
\hline $\mathrm{Total}$ & 100.19 & 99.99 & 100.75 & 103.33 & 100.14 & 100.14 & 99.76 & 100.43 \\
\hline $\mathrm{Si}$ & 2.987 & 2.977 & 3.005 & 2.955 & 3.003 & 3.008 & 2.995 & 3.014 \\
\hline $\mathrm{Ti}$ & 0.019 & 0.006 & 0.000 & 0.000 & 0.004 & 0.004 & 0.008 & 0.000 \\
\hline $\mathrm{Al}$ & 1.946 & 1.923 & 1.963 & 2.025 & 1.940 & 1.956 & 1.965 & 1.960 \\
\hline $\mathrm{Fe}{ }^{3+}$ & 0.042 & 0.101 & 0.025 & 0.065 & 0.046 & 0.020 & 0.028 & 0.010 \\
\hline $\mathrm{Mg}$ & 0.049 & 0.168 & 0.277 & 0.490 & 0.214 & 0.345 & 0.000 & 0.376 \\
\hline $\mathrm{Fe}{ }^{2+}$ & 0.249 & 1.261 & 1.453 & 0.854 & 1.176 & 1.433 & 0.858 & 1.858 \\
\hline $\mathrm{Mn}$ & 2.463 & 1.520 & 0.996 & 1.480 & 0.953 & 0.635 & 1.216 & 0.441 \\
\hline $\mathrm{Ca}$ & 0.244 & 0.034 & 0.279 & 0.131 & 0.663 & 0.599 & 0.930 & 0.339 \\
\hline $\mathrm{Y}$ & 0.000 & 0.011 & 0.003 & 0.000 & 0.000 & 0.000 & 0.000 & 0.003 \\
\hline $\mathrm{LCat.}$ & 8.000 & 8.000 & 8.000 & 8.000 & 8.000 & 8.000 & 8.000 & 8.000 \\
\hline $\mathrm{Alm}$ & 8 & 41 & 48 & 29 & 39 & 47 & 28 & 61 \\
\hline $\mathrm{Adr}$ & 2 & 1 & 1 & 3 & 2 & 1 & 1 & 1 \\
\hline $\mathrm{Grs}$ & 6 & 0 & 8 & 1 & 20 & 19 & 30 & 11 \\
\hline $\mathrm{Prp}$ & 2 & 6 & 9 & 17 & 7 & 12 & 0 & 13 \\
\hline $\mathrm{Sps}$ & 83 & 52 & 33 & 50 & 32 & 21 & 41 & 15 \\
\hline & & & & & & & & \\
\hline
\end{tabular}


Zircon strongly dominates in the translucent heavy mineral assemblage of quartz to arkosic sandstone, forming $60.5 \mathrm{wt} . \%$. Rutile (13.0 wt.\%), apatite (13.0 wt.\%), garnet (9.5 wt.\%), and tourmaline (2.5 wt.\%) represent the further typical heavy minerals. Monazite, minerals of the epidote group, and titanite are only accessory (never exceeding $1.5 \mathrm{wt} . \%$ ).

The chemical composition of two heavy minerals, i.e. garnet and tourmaline, was studied in detail (Tables 1 and 2). It was possible to fully analyse only five grains of Fe-dravite to Al-schorl tourmaline $[\mathrm{Fe} /(\mathrm{Fe}+\mathrm{Mg})=0.38-0.77 ; \mathrm{Na}=0.56-0.77 ; \mathrm{Al}=$ 6.1-6.5 apfu] (Fig. 7A) . Individual grains show oscillatory zoning, controlled mainly by foitite substitution $\square \mathrm{Al} \mathrm{Na} \mathrm{Na}_{1}(\mathrm{Fe}, \mathrm{Mg})_{-1}$ and the contents of $\mathrm{Ca}(0.01-0.07 \mathrm{apfu})$ and $\mathrm{F}(0.00-0.18 \mathrm{apfu})$ are low. The analysis of garnet composition (8 grains) revealed the strong dominance (about $66 \%$ ) of almandine-spessartine-grossular garnet $\left(\mathrm{Alm}_{28-61} \mathrm{Sps}_{15-40} \mathrm{Grs}_{8-30} \mathrm{Adr}_{1-2} \operatorname{Prp}_{0-12}\right)$. The rest (34\%) is formed mostly by the spessartine type of garnet ( $\mathrm{Sps}_{50-83}$ $\mathrm{Alm}_{8-41} \operatorname{Prp}_{2-17} \mathrm{Grs}_{0-6} \mathrm{Adr}_{1-3}$ ).

\section{PROVENANCE STUDY}

The content of the ultra-stable heavy minerals (tourmaline + zircon + rutile) is very high (89.5 wt. \%). Angular zircons dominate, constituting $60.5 \mathrm{wt} . \%$ of the spectra of translucent heavy minerals. The high content of the ultra-stable minerals, together with the absolute dominance of quartz grains, indicates a deeply weathered source area and/or a source from repeatedly recycled older deposits.

The important role of acidic magmatic rocks, i.e. granites and granodiorites, in the predicted primary source seems to be confirmed by the common occurrence of clasts of granitoids $(\mathrm{Kfs}+\mathrm{Qtz} \pm \mathrm{Pl})$, as well as fragments of perthitic K-feldspar. Fragments of acidic volcanic rocks, quartzites, and gneisses were also recognized. Cathodoluminescence $(\mathrm{CL})$ shows several sources of quartz grains. Bright red luminescence is typical of high-temperature quartz derived from volcanic rocks, such as rhyolite. Quartz with light blue luminescence was probably de-

Table 2

Representative chemical composition of tourmaline

\begin{tabular}{|c|c|c|c|c|c|}
\hline Grain & HG16/1 & HG16/2 & HG16/3 & HG16/4 & $\mathrm{HG} 16 / 5$ \\
\hline $\mathrm{SiO}_{2}$ & 36.84 & 35.59 & 35.93 & 37.44 & 36.11 \\
\hline $\mathrm{TiO}_{2}$ & 0.09 & 0.33 & 0.27 & 0.09 & 0.11 \\
\hline $\mathrm{Al}_{2} \mathrm{O}_{3}$ & 32.26 & 31.19 & 31.89 & 31.78 & 32.96 \\
\hline $\mathrm{Cr}_{2} \mathrm{O}_{3}$ & 0.00 & 0.01 & 0.01 & 0.04 & 0.02 \\
\hline $\mathrm{FeO}$ & 9.17 & 12.68 & 11.30 & 7.74 & 12.97 \\
\hline $\mathrm{MgO}$ & 5.79 & 3.75 & 3.62 & 7.06 & 2.17 \\
\hline $\mathrm{CaO}$ & 0.40 & 0.22 & 0.29 & 0.16 & 0.08 \\
\hline $\mathrm{MnO}$ & 0.19 & 0.07 & 0.00 & 0.02 & 0.26 \\
\hline $\mathrm{Na}_{2} \mathrm{O}$ & 2.30 & 2.37 & 1.72 & 2.21 & 1.72 \\
\hline $\mathrm{K}_{2} \mathrm{O}$ & 0.05 & 0.06 & 0.02 & 0.01 & 0.03 \\
\hline $\mathrm{F}$ & 0.00 & 0.34 & 0.05 & 0.00 & 0.00 \\
\hline $\mathrm{H}_{2} \mathrm{O}$ * & 3.67 & 3.40 & 3.54 & 3.69 & 3.59 \\
\hline $\mathrm{B}_{2} \mathrm{O}_{3}$ * & 10.64 & 10.33 & 10.32 & 10.68 & 10.41 \\
\hline $\mathrm{O}=\mathrm{F}$ & 0.00 & 0.14 & 0.02 & 0.00 & 0.00 \\
\hline Total & 101.39 & 100.21 & 98.92 & 100.91 & 100.43 \\
\hline \multicolumn{6}{|c|}{ Position $T+Z+Y$} \\
\hline $\mathrm{Si}^{4+}$ & 6.018 & 5.987 & 6.051 & 6.092 & 6.028 \\
\hline $\mathrm{Al}^{3+}$ & 6.211 & 6.183 & 6.329 & 6.094 & 6.486 \\
\hline $\mathrm{Ti}^{4+}$ & 0.011 & 0.042 & 0.034 & 0.011 & 0.014 \\
\hline $\mathrm{Fe}^{2+}$ & 1.252 & 1.784 & 1.592 & 1.053 & 1.810 \\
\hline $\mathrm{Mg}^{2+}$ & 1.409 & 0.941 & 0.909 & 1.712 & 0.541 \\
\hline $\mathrm{Mn}^{2+}$ & 0.027 & 0.010 & 0.000 & 0.002 & 0.037 \\
\hline $\mathrm{Cr}^{3+}$ & 0.000 & 0.001 & 0.001 & 0.006 & 0.002 \\
\hline \multicolumn{6}{|c|}{ Position X } \\
\hline $\mathrm{Ca}^{2+}$ & 0.069 & 0.039 & 0.052 & 0.029 & 0.014 \\
\hline $\mathrm{Na}^{+}$ & 0.729 & 0.773 & 0.562 & 0.697 & 0.555 \\
\hline $\mathrm{K}^{+}$ & 0.009 & 0.012 & 0.004 & 0.001 & 0.007 \\
\hline Vacancy & 0.192 & 0.176 & 0.383 & 0.273 & 0.423 \\
\hline $\mathrm{OH}$ & 4.000 & 3.818 & 3.975 & 4.000 & 4.000 \\
\hline $\mathrm{F}^{-}$ & 0.000 & 0.182 & 0.025 & 0.000 & 0.000 \\
\hline $\mathrm{B}^{3+}$ & 3.000 & 3.000 & 3.000 & 3.000 & 3.000 \\
\hline
\end{tabular}


rived from acid plutonic rocks, such as granite. The grains with clear blue luminescence were probably derived either from granite or high-grade gneiss. The quartz grains without CL were probably derived from low-temperature source rocks, for example, older sedimentary rocks or low-grade metasedimentary rocks (Nehyba et al., 2001).

Similar spectra of rocks are characteristic of Brunovistulicum (see Dudek, 1995; Finger et al., 2000), thus, this geological unit is the most probable source area of siliciclastic rocks at the Babí lom locality.
The chemical composition of the garnets and tourmalines studied is also comparable to the composition of these minerals from Brunovistulicum rocks (see Leichmann, 1996; Čopjaková, 2007; Buriánek, 2010). Garnets can be derived from the following source areas: rhyolites of the Metadiorite Zone of the Central Basic Belt of the Brno Massif and/or granodiorites, granites, pegmatites, gneisses, and calc-silicate rocks of Brunovistulicum (Fig. 7B). Similarly, some tourmalines were probably derived from hydrothermal quartz veins of the Metadiorite Zone of the Brno Batholith, and/or from rhyolites (probably of early Paleozoic

A

X-Site Vacant



Fig. 7. Chemical composition of tourmalines and garnets within sandstones from the Babí Lom locality compared with supposed source rocks from the Brunovistulicum

A - ternary plots Fe-Mg-Al and $\mathrm{Na}+\mathrm{K}-\mathrm{Ca}^{-\mathrm{X}}$ for tourmalines; $\mathrm{B}$ - ternary plots Sps-Alm-Grs+Adr, Prp-Sps-Grs+Adr, Prp-Grs+Adr-Alm for garnets 
age; Buriánek and Gilíková 2011). Granites that contain tourmaline are rare in recent erosional levels of the Brno Batholith, but may be present in the rocks of its upper levels (Fig. 7A).

\section{CONCLUSIONS}

Despite tectonic deformation of the Devonian siliciclastic rocks in the Babí lom locality, it was possible to identify the primary textural and structural sedimentary features, such as clast imbrication, cross-bedding, erosional surfaces, pebble clusters, and others.

The deposits studied accumulated in a terrestrial setting: first in a meandering river, then in a braided river, and finally on an alluvial fan.
The high maturity of the sediments suggests that sedimentary material was derived from older deposits and/or highly weathered source rocks. The magmatic rocks of Brunovistulicum are postulated as the primary source of the sediments.

Assuming that the Devonian rocks cropping out at the Babí lom locality have not been rotated laterally, it can be deduced that the source area was located to the east, but the dominant palaeotransport was towards the north.

Acknowledgements. The paper was supported by the following grants: Czech Geological Survey 390003 - Basic Geological Mapping of the Brno Agglomeration and the Moravian Karst, scale 1:25 000 and 1017/S/ING - internal grant of Wrocław University. The support is gratefully acknowledged. We give thanks for helpful discussions to $S$. Burliga, and for reviews to J. Otava, A. Prichystal and A. Wysocka.

\section{REFERENCES}

Allen, J.R.L., 1964. Studies in fluviatile sedimentation: six cyclothems from the Lower Old Red Sandstone, Anglo-Welsh Basin. Sedimentology, 3: 163-198.

Bentham, P.A., Talling, P.J., Burbank, D.W., 1993. Braided stream and floodplain deposition in a rapidly aggrading basin: the Escanilla Formation, Spanish Pyrenees. Geological Society Special Publications, 75: 177-194.

Blair, T.C., 1999. Sedimentary processes and facies of the waterlaid Anvil Spring Canyon alluvial fan, Death Valley, California. Sedimentology, 46: 913-940.

Blair, T.C., McPherson, J.C., 1994. Alluvial fans and their natural distinction from rivers based on morphology, hydraulic processes, sedimentary processes, and facies assemblages. Journal of Sedimentary Research, A64: 450-489.

Bridge, J.S., 1993. Description and interpretation of fluvial deposits: a critical perspective. Sedimentology, 40: 801-810.

Buriánek, D., 2010. Metamorphic evolution metadiorite subzone in the Brno batholith (in Czech with English summary). Acta Musei Moraviae, Scientae Geologicae, 2: 151-170.

Buriánek, D., Gilíková, H., 2011. Rhyolites from Metadiorite Zone of the Brno Massif (in Czech). Geological Research in Moravia and Silesia, 18: 118-124.

Buriánek, D., Gilíková, H., Nehyba, S., Otava, J., 2008. Translucent heavy minerals from siliciclastic sediments of the Cambrian and Devonian age, SE Moravia, Czech Republic, case study of provenance and sedimentology (in Czech with English summary). Acta Musei Moraviae, Scientae Geologicae, 93: 169-184.

Čopjaková, R., 2007. Odraz změn provenience v psefitické a psamitické frakci sedimentů myslejovického souvrství (in Czech with English summary). Ph.D. thesis, Faculty of Science Masaryk University, Brno.

Desloges, J.R., Church, M., 1987. Channel and floodplain facies in a wandering gravel-bed river. SEPM Special Publication, 39: $99-110$.

Dudek, A., 1995. Metamorphic evolution of the Moravo-Silesian basement. In: Pre-Permian Geology of Central and Eastern Europe (eds. R. D. Dallmeyer, W. Franke and K. Weber): 508-511. Springer, Berlin.

Dvořák, J., 1960. Zpráva o geologickém mapování devonských a spodnokarbonských ostrůvků na brněnské vyvřelině (in Czech). Archiv ÚúG.
Dvořák, J., 1978. Geologie paleozoika v podloží Karpat jv. od Drahanské vrchoviny (in Czech). Zemní Plyn Nafta, 2: 185-203.

Dvořák, J., 1998. Lower Devonian basal clastics Old Red Formation, Southern Moravia, Czech Republic. Czech Geological Survey Bulletin, 4: 271-279.

Finger, F., Hanžl, P., Pin, C., Von, Q.A., Steyrer, H.P., 2000. The Brunovistulian: Avalonian Precambrian sequence at the eastern end of the Central European Variscides? Geological Society Special Publications, 179: 103-112.

Gilíková, H., 2007. Petrology composition and the sedimentary environments of the Lower Paleozoic (Cambrian-Devonian) clastic sediments (in Czech with English summary). Ph.D. thesis, Faculty of Science, Masaryk University, Brno.

Gilíková, H., Hladil, J., Bubík, M., Černý, J., Hrdličková, K., Kunceová, E., Melichar, R., Otava, J., Tomanová-Petrová, P., Vít, J., 2010. Basic geological map of the Czech Republic 1:25 000, sheet 24-413 Mokrá-Horákov (in Czech). Archiv, Czech Geological Survey, Prague.

Graham, J., 2004. Collection and analysis of field data. In: Techniques in Sedimentology (ed. M. Tucker): 5-63. Blackwell Science.

Hampton, B.A., Horton, B.K., 2007. Sheetflow fluvial processes in a rapidly subsiding basin, Altiplano plateau, Bolivia. Sedimentology, 54: 1121-1147.

Hanžl, P., Buriánková, K., Čech, S., Čtyroká, J., Čurda, J., Gilíková, H., Hradecká, L., Hubatka, F., Janoušek, V., Kašpárek, M., Manová, M., Maštera, L., Otava, J., Petrová, P., Šalanský, K., Šrámek, J., Vít, J., 2007. Explanatory text to Basic geological map of the Czech Republic 1:25 000 sheet 24-322 Blansko. Czech Geological Survey, Prague.

Hein, F.J., 1984. Deep-sea and fluvial braided channel conglomerates: a comparison of two case studies. Canadian Society of Petroleum Geologists Memoir, 10: 33-49.

Hladil, J., 1992. Čelechovické Vápence v Deformačních Strukturách na v. Okraji Boskovické Brázdy (in Czech). Geoscience Research Reports for 1990, 55.

Jackson, R.G., 1978. Preliminary evaluation of lithofacies models for meandering alluvial streams. Canadian Society of Petroleum Geologists Memoir, 5: 543-576.

Jackson, R.G., 1981. Sedimentology of muddy fine-grained channel deposits in meandering streams of the American Middle West. Journal of Sedimentary Petrology, 51: 1169-1192. 
Kretz, R., 1983. Symbols for rock forming minerals. American Mineralogist, 68: 277-279.

Leichmann, J., 1996. Geologie und Petrologie des Bruenner Massivs. Ph.D. thesis, Universität Salzburg.

Mack, G.H., Seager, W.R., 1990. Tectonic control on facies distribution of the Camp Rice and Palomas Formations (Plio-Pleistocene) in the Southern Rio Grande rift. GSA Bulletin, 102: 45-53.

Melichar, R., Hubatka, F., Hanžl, P., 1999. Stop 1 - Babí lom. Geolines, 8: 81-83.

Miall, A.D., 1985. Architectural-element analysis: a new method of facies analysis applied to fluvial deposits. Earth-Science Reviews, 22: 261-308.

Miall, A. D., 1996. The Geology of Fluvial Deposits. Springer, Berlin.

Mikuláš, R., Gilíková, H., Vavrdová M., 2008. Late Proterozoic to Early Palaeozoic platform deposits of Southern Moravia (Czech Republic). Geological Quarterly, 52 (4): 335-348.

Nehyba, S., Leichmann, J., Kalvoda, J., 2001. Depositional environment of the "Old Red" sediments in the Brno area (south-eastern part of the Rhenohercynian zone, Bohemian Massif). Geologica Carpathica, 52: 195-208.

Roupec, P., 1994. Analýza napě ového pole ze střižných zón se stylolity na lokalitě Babí lom u Brna (in Czech). Věstník Českého Geologického Ústavu, 69: 69-72.
Skoček, V., 1980. New findings about lithology of Devonian basal clastics of Moravia (in Czech). Czech Geological Survey Bulletin, 55: 27-37.

Teisseyre, A.K., 1977. Pebble clusters as a directional structure in fluvial gravels: modern and ancient examples. Geologia Sudetica, 12: 79-90.

Todd, S.P., 1989. Stream-driven, high-density gravelly traction carpets: possible deposits in the Trabeg Conglomerate Formation, SW Ireland and some theoretical considerations of their origin. Sedimentology, 36: 513-530.

Vavrdová, M., Mlikuláš, R., Nehyba, S., 2003. Lower Cambrian siliciclastic sediments in Southern Moravia (Czech Republic) and their paleogeographical constraints. Geologica Carpathica, 52: 67-79.

Walker, R.G., James, N.P., eds., 1992. Facies Models. Response to Sea Level Changes. Geological Association of Canada.

Wittenberg, L., Newson, M.D., 2005. Particle clusters in gravel-bed rivers: an experimental morphological approach to bed material transport and stability concepts. Earth Surface Processes and Landforms, 30: 1351-1368.

Zukalová, V., Chlupáč, I., 1982. Stratigraphic classification of the non-metamorphosed Devonian of the Moravo-Silesian region. Časopis pro Mineralogii a Geologii, 9: 225-247. 